\title{
RETHINKING THE TRANSLATOR'S ROLE WITHIN THE GILT PROJECT: AN INTEGRATED APPROACH
}

\author{
Irina N. Remkhe ${ }^{1}$, Liliya A. Nefedova ${ }^{1}$, \\ David C. Gillespie ${ }^{2}$ \\ ${ }^{1}$ Chelyabinsk State University \\ Bratyev Kashirinykh Str., 129, Chelyabinsk, Russia, 454001 \\ ${ }^{2}$ University of Bath \\ Claverton Down, Bath, North East Somerset BA2 7AY, United Kingdom
}

\begin{abstract}
Over the last few decades the scope of the translator's role has extended from being a mediator between source and target texts and is now seen within a purely linguistic approach to establishing his/her own integrated dynamic reality of digital texts and virtual database. Within an integrated approach, we propose that equivalence can be considered from the neutralized position of a translator who needs to conform with translational norms as well as render the communicative purpose of the sender; the text content includes stylistic peculiarities and non-verbal information. In terms of the localization industry, the leading factor should be translational norms incorporated into the system with the help of special software to determine certain modes of translation, the foreignizing mode, domesticating mode, internationalizing mode, and localization mode. With the GILT paradigm the translation model is developing into a new concept that consolidates complex integrated solutions for the translation process.
\end{abstract}

Keywords: integrated approach, translation model, equivalence, localization, internationalization

\section{INTRODUCTION}

The field of translation studies over the years has seen plenty of trends and approaches, all of which are of paramount importance. Scopos Theory, Polysystem Theory, Descriptive Translation Studies, the School of Manipulation and Postcolonial Translation Theory are classical trends mentioned in various works on translation and represent a substantial corpus of groundwork on translation studies as a whole.

However, with such a diversity of theories, there seems to be no agreement yet among scholars on accepting a fundamental fact: translations should be studied from an integrated perspective. We propose that there needs to be an explicit attempt to integrate most recognizable approaches in order to work out one unifying paradigm, which then could explain the complexity of the translation process. This should satisfy the cognitive need for mapping the translation process as an integrated model within a holistic point of view. On a larger scale, with every new approach the integration should be further developed, providing a continuous dynamic forward movement of the translation discipline.

In this study we will present our view of shifting the role of the translator in the rapidly changing and expanding field of translation studies, with an emphasis on the contemporary trends of internalization and localization as a new challenge. In view of this, 
it is exploring advanced technologies used by translators. The case study and research questions are applied to produce a balanced view on bridging translation barriers and adapting the original text as part of a dynamic and integrated model of the translation process based on traditional concepts of correspondence and equivalence.

\section{FINDINGS ON THE ISSUE OF EQUIVALENCE IN TRANSLATION}

Translation initially emerged as a linguistic phenomenon, as a process of meaning transfer through linguistic transcoding. Therefore, the linguistic approach to translation primarily focuses on the issues of meaning and equivalence and is aimed at giving a precise description of equivalence relations between signs and combinations of them in the SL (source language) and in the TL (target language). Attempts were made to provide systematic analyses based on certain linguistic issues, such as meaning and "equivalence" by R. Jakobson (1959/2000), "seminal concepts of formal and dynamic equivalence" by E. Nida (1964), "a rank-bound equivalence concept" by J.C. Catford (1965) and "semantic and communicative translation" by P. Newmark (1981).

In the development of the foundations of Translation Studies in the 1950s there was a clear influence of Western scholars on Russian linguists, specifically with respect to the concept of equivalence and translatability in the sense that, as Jakobson wrote, linguistics should affect the study of translation (Jakobson 1959: 233 - 234).

In his most recognized work A Linguistic Theory of Translation, Catford confirms: "Clearly, then, any theory of translation must draw upon a theory of language - a general linguistic theory" (Catford 1965: 56).

At some point the term "equivalence" moved to Russian translation theory and soon replaced a similar Russian concept of "sootvetstviye" [correspondence] in order to conform with international terminology and later seen as a broader concept that allowed the translator to extend the word-to-word and sense-to-sense concept in the works of Komissarov and Shveitser. In Komissarov's best-known book Slovo o Perevode [A Discourse on Translation] equivalence is described within five levels of content: "1) linguistic sign; 2) expression; 3) message; 4) description of the situation; 5) communication objective. The major goal of translation is to establish the maximum degree of equivalence on each level" (Komissarov 1973: 76-77).

This, however, is reminiscent of Catford's rank-bound equivalence (1965) which is opposed to unbounded translation. In rank-bound translation equivalences are tied to a certain rank or as word-to-word and morpheme-to-morpheme equivalences. In unbounded translation, the levels are extended to sentence, clause and other factors.

In an effort to answer the question of what is equivalent to what, Koller distinguishes five different types of equivalence: (a) denotative equivalence involving the extralinguistic content of a text, (b) connotative equivalence relating to lexical choices, (c) text-normative equivalence relating to text-types, (d) pragmatic equivalence involving the receiver of the text or message, and, finally, (e) formal equivalence relating to the form and aesthetics of the text (pp. 186-191). (cf. Panou 2013: 186-191).

A classification of correspondence in translation in the traditional Soviet sense is suggested in Retsker's Teoriya Perevoda i Perevodcheskaya Praktika [The Theory of Translation and Translation Practice]. The categories are as follows: 1) equivalence; 
2) variant and contextual correspondence; 3) translation transformations of various types. In terms of equivalence, Retsker differentiates it in both a narrow and expanded sense, where the former implies "translation equivalence that does not depend on a context (Retsker 1974: 13).

In Retsker's subsequent discussions, it becomes clear that he would stick to the narrow sense of equivalence as "the catalysts in the process of translation" (Retsker 1974: 15).

Etymologically the term "equivalence" in the Russian traditional school of translation can be seen as a shift from its original meaning of "substitution" through "transformation" and on to a broader sense of "adequacy" as opposed to "equivalence" assumed by Shveitser (1988). The same opposition is observed in the works of Reiss and Vermeer (1984/1991). The words "target" and "purpose" were already mentioned in the early works of Shveitser and Fedorov (1953) which were primarily determined by the development of the Skopos theory.

The shift to the transformational sense of equivalence can be explained by the emergence of transformation linguistics, specifically in the works of Chomsky and the development of machine translation. In addition, it is important to mention Nida's move towards the "functional definition of meaning in which a word "acquires" meaning through its context and can produce various responses according to culture" [cited by Munday 2008: 42]. The concept of formal and dynamic equivalence put forward by Nida became fundamental for the new understanding of the "naturalness" of translation. As Munday concludes: "The message has to be tailored to the receptor's linguistic needs and cultural expectation and aims at complete naturalness of expression" (Munday 2008: 42).

This interpretation provided by Munday, reflects the essence of the GILT strategy, which will be discussed later in this paper.

So, while in Western academic discourse the term "equivalence" started to be used in a more general sense (Vinay \& Darbelnet, Catford), in Russian translation theory at that time equivalence was mostly considered between narrow categories. The broader sense was adopted later in the 1970s with Western views being constantly incorporated into Soviet translation theory. All in all, the most valuable consequence of the ideas of the Leipzig school and its followers (Kade, Fedorov, Komissarov, House, Hatim, Shveitser, Wills etc.) lies in the development of Translation Studies as an empiricallybased academic discipline.

\section{GILT: A NEW SCOPE OF THE OLD PARADIGM}

\subsection{Defining globalization, internationalization and localization}

With the advent of the digital revolution in the 1980s the idea of the text for translation evolved into a new concept. Since then the text has acquired digital content containing pictures, diagrams, company logos, images, graphics, animation and software. Thus, the text was often included in the software and needed to be localized to serve the company's purposes and the target culture's preferences. Therefore, the term "localization" appeared, which, in a broader sense, means a "high-tech" translation, since it 
deals with non-textual components in addition to the translation itself. This greatly affected the role of the translator and reshaped the translation model by shifting sides and priorities.

The terms Globalization, Internationalization, Localization and Translation are blended into the abbreviation GILT, which signifies a combined chain of strategies/steps to deliver the final product to the target consumer.

The definitions of these terms are explicitly explained in Pym's book The Moving Text: Globalization: addresses the business issues associated with making a product global. The globalization of high-tech products involves integrating localization throughout a company, after proper internationalization and product design, as well as marketing, sales, and support in the world market; Internationalization: the process of generalizing a product so that it can handle multiple languages and cultural conventions without the need for redesign. Internationalization takes place at the level of program design [in the case of software] and document development; Localization: taking a product and making it linguistically and culturally appropriate to the target locale (country/region and language) where it will be used and sold (Pym 2004: 29-30).

Considering the complexity of the stages, and the people involved, the differences should be analyzed from the point of view of the cooperative efforts and the degree of contribution made by each member of the process (Table 1).

Differences between internationalization, localization, and globalization

\begin{tabular}{|l|l|l|l|}
\hline & \multicolumn{1}{|c|}{ Internationalization } & \multicolumn{1}{c|}{ Localization } & \multicolumn{1}{c|}{ Globalization } \\
\hline Definition & $\begin{array}{l}\text { Functional in any language } \\
\text { and content (linguistic and } \\
\text { cultural data) separated } \\
\text { from functionality }\end{array}$ & $\begin{array}{l}\text { Adaptation of products, ser- } \\
\text { vices, and digital content to } \\
\text { a cultural and linguistic mar- } \\
\text { ket }\end{array}$ & $\begin{array}{l}\text { The strategy of bringing a } \\
\text { product or service to the } \\
\text { global market, involving } \\
\text { sales and marketing }\end{array}$ \\
\hline People & $\begin{array}{l}\text { Software developers, produ- } \\
\text { cers and authors of digital } \\
\text { content }\end{array}$ & $\begin{array}{l}\text { Translators, proofreaders, } \\
\text { software engineers, project } \\
\text { managers, testers, publishers }\end{array}$ & $\begin{array}{l}\text { Marketing and sales per- } \\
\text { sonnel }\end{array}$ \\
\hline $\begin{array}{l}\text { Sevelopment and design of } \\
\text { a digital product (content) } \\
\text { or service (pre-requisite for } \\
\text { localization) }\end{array}$ & $\begin{array}{l}\text { Translation and adaptation } \\
\text { of text, user interface, and } \\
\text { cultural conventions }\end{array}$ & $\begin{array}{l}\text { Bringing to the market the } \\
\text { internationalized and local- } \\
\text { ized product or service }\end{array}$ \\
\hline
\end{tabular}

In Pym's book The Moving Text the process of internationalization is described as several practices placed between the two extremes of "pretranslation" and "adoption of lingua franca for production purposes". These practices include "an extension of category superordinates, which is the compiling of multilingual terminology databases", "a further extension is the use of controlled input language", "reduced lexis and limited syntactic resources precisely so that ambiguities are avoided when being localized" and "glossing locale specific items in such a way that the added information makes their meaning unambiguous" (Pym 2004: 33).

Localization goes beyond translation and is aimed at adapting the source text content to the target culture or place where the translated text is intended for use. It refers to the adaptation of a product, application or document content to meet the linguistic, cultural and other requirements of a specific target market (a locale). This definition brings back the concept of "naturalness" of translation put forward in Nida's works 
when "the message has to be tailored to the receptor's linguistic needs and cultural expectation" (cf. Munday 2008: 39) since localization is also about tailoring a product to an individual local market.

Among the defining characteristics of localization, there is an extraction-adaptation-integration process clearly explained by Dunne: "The development team could simply extract the resources from the binary executable file, provide them to a localization team that would translate the text and perform all other necessary modifications and then return the target resources to the developers, who would integrate them into copies of the binary executable file to create the necessary target version or versions" (Dunne 2015: 556). Thus, the localization phenomenon is conceived as a cultural "transplant" extracted from the binary executable file and integrated into user interface material to be stored for a specific target reader.

Technical translators become technical communicators and can at any time change direction to become "technical writers". The advantages of this semi-translation career are discussed by Olohan: "Technical writers are usually responsible for creating, maintaining and managing documentation of various kinds, for example technical specifications, product descriptions, service descriptions, instruction manuals, user guides, wikis and tutorials" (Olohan 2016: 13-14). Translation has always been done for specific purposes and aimed at specific users, so in some respect it seems natural that translation is only part of the localization process. Besides, specialized translation is often seen as group work with IT engineers and experts in the field involved to increase efficiency and conform to standards. Within the localization industry, translation goes together with project management and product engineering.

\subsection{Equivalence as a descriptive concept}

There is an ongoing discussion among linguists regarding the role of the translator in an era of new technologies and automated systems. From the critical point of view, there is no shift forward and the same traditional concept of equivalence is being applied to the translation process. We will address this issue from a neutral position, considering both sides of the argument, and put forward our proposition for a translation process as an integrated reality, an idea expanded and developed from Mary Snell-Hornby Translation Studies. An Integrated Approach (Snell-Hornby 1988).

The new paradigm of GILT introduces a new translation technology which will make us reconsider the essence of the translation process and the way it is modelled. Nowadays translations are carried out by teams of professionals under the supervision of a project manager, all working in a specially designed technically integrated area on the same translation project. As B. Esselink puts it: "Ideally, translators should sit at the same desk as the software developers and technical authors, translate all of the content simultaneously" (Esselink 2000: 478). This allows translation costs to be reduced, the level of competitiveness to be raised and the translation process as such to be facilitated and enhanced.

It is claimed that translators are being separated from the humanizing discourse and even from the marketing, which could be a rather lucrative perspective. Being restricted by norms and system standards, they seem to be returning to the narrow equivalence approach. 
On the one hand, the role of a translator has shifted from the clear central position of the anthropocentric approach to some ambiguous areas where personal competence is replaced by automation and technologically advanced computer-aided systems. As Olohan summarizes: "The localization sector requires linguists for the translation roles, but also those who have additional expertise, for example in testing software products" (Olohan 2016: 13).

From the intercultural point of view, there is no close relationship between a source text and a target text. The relationship proceeds from a source text somewhere to an internationalized product and then from there into many localized products at once, or, in other words, to many target cultures. Besides, within localization translators work on projects and translators become small objects, fragments or chunks, which have fixed content in terms of convention, artificial syntax and controlled writing. Thus, their translations are targeted at "users" not "readers" who want to understand the information quickly. In other words, communication is now an internationalized object and has been removed from the culture to be placed in the technical sphere. As Pym correctly assumes: "All texts become "information objects"" (Hofmann and Mehnert 2000), "information elements" (Lockwood 2000), fragments of a textual whole that is not named because it is never seen. Such is non-linearity. And it might be a feature of the kind of discourse produced by internationalization in an electronic age" (Pym 2004:186)

The growing tendency towards non-linearity and fragmentation is the result of dramatic changes in increasing data volumes which has facilitated not only the growing abundance of translation tools and technologies, but also the remapping of the translation process. Nowadays "translators and localizers do not work on linear text but rather on decontexualized text strings or chunks" (Dunne 2015: 560).

Informational and linguistic structuring of texts takes the leading role in forming target texts for readers with technical structuring seen as more important than the narration itself, which is succinctly explained by Pym: Texts are structured in terms of repetition rather than deictics, hyperlinks rather than hypotaxis, and text length has no socially necessary restriction. All this, of course, comes just when linguistics has established disciplines given to analyzing the way texts are put together, in the very age when electronic texts are becoming stand-alone chunks (Pym 2004: 186).

Considering that translation is operating on the basis of equivalence, the level of competence is diminishing and translation as such, as Pym asserts, is viewed as "a textreplacement process suited to natural-language strings". Within internationalization, nevertheless, there remains a variety of ways to build equivalence prior to the moment of translation. Indeed, were internationalization in any way complete, translation would become an uninteresting automatic process of simply producing equivalence: "just a language problem" <...> Internationalization has as one of its prime tasks the efficient assurance of equivalence in translation" (Pym 2004: 54).

With the empirical "turn" and the globalization "turn", described by Mary SnellHornby in her book The Turns of Translation Studies: New Paradigms or Shifting Viewpoints?, the issues of technology, business and other international discourse become relevant. With the dominance of technology we have witnessed radical changes in the "language material" globally understood as "text". Mary Snell-Hornby summarizes this as follows: 1. Due to the vast amount of material transmitted by telecommunication, 
the speech with which it is processed, the increasing use of colloquial forms and the tolerance of what were traditionally viewed as language mistakes or typing errors, some communication relies simply on basic mutual intelligibility, and here translation has to some extent been made obsolete (much communication is carried out in the lingua franca of English. Formal business correspondence has partly been replaced by informal e-mail correspondence, much is dealt with by fax and mobile phone. 2 . The same necessity for speedy processing and the tolerance of less than impeccable language forms, along with the levelling of culture-specific differences within the technological "lingua franca", mean a potentially greater role for machine translation (e.g. as "gisting", or rough versions of insider information for internal use within a concern). 3. Multimedia communication creates new text types (the audio museum guide is one example), some of them multisemiotic, with the verbal signs interacting with icons, layout tricks, pictorial images and sounds (as can increasingly be seen in advertising techniques). 4. In the area of intercultural communication, requiring not only language mediation but heightened cultural expertise, the (human) translator (and interpreter) plays an increasingly important role, whereby he/she will take the full responsibility for the "final product" (Snell-Hornby 2006: 133).

Working on decontextualized text strings or chunks raises the issue of translator's decision-making process and understanding. Lack of context calls into question the cognitive and pragmatic act of communication. As was stated in our earlier work, "the translation process is a conglomerate of various modelling tools depending on the peculiarities of the translation scheme and the translator's mental activities, i.e. identification, simultaneous or successive processing, reframing, finding conceptual correlations and reaching pragmatic and communicative goals. The overlapping parts signify connections and interaction between the elements that are activated due to the synergetic and dynamic potential of the system (Remkhe 2016: 238).

The necessity of working in small text fragments is paving the way back to equivalence in the narrow linguistic sense of the 1950s, with the translator using translation memory and being locked into other localization project tools. If we take a closer look at text processing from the point of view of linguistic generalizations, the rule-based strategy is becoming more explicit. Within large quantitative databases based on statistical patterns we are returning to the approach of phrase-to-phrase and word-to-word correspondence between texts. This correspondence can be established by machinebased matching equivalences (statistical machine translation) or generalizing them (example-based translation). With the development of parallel corpora resources, we are now witnessing the advent of robust and self-learning translation software.

However, within an integrated approach, we believe that equivalence can be considered from the neutralized position of a translator who needs to conform to translational norms as well as render the communicative purpose of the sender (pragmatic element), text content (semantic element) including stylistic peculiarities and non-verbal information (images). Thus, we agree with the term "default equivalence position" suggested by Cuellar: "Since the translated text is largely "imbedded in a socio-cultural context different from the context of the SL community', equivalence can be used as a descriptive concept for ascertaining compliance with any given translational norm valid in the 
target community for the specific translated text type, together with the fulfilment of the initiator's 'translational instructions"' (Cuellar 2008: 180).

In terms of the localization industry, the leading factor should be translational norms incorporated into the system with the help of special software to determine the following modes of translation:

- closeness to the original (foreignizing mode);

— closeness to the target readership, adjusting strategies (domesticating mode);

- closeness to the default equivalence position (internationalizing mode);

- adapting the original's terminology to national varieties of the target reader/user (localization mode).

In the event that equivalence is not considered as a strictly normative concept, we can come to an agreement between existing compulsory translational norms and the possibility to alter them depending on the translation task, instructions given by the initiator and the purpose of the translation. This will help the translation role remain important so that it cannot be replaced with automated systems, since a machine is not able to adjust or adapt easily while overriding translation norms or predetermined units.

\section{METHODOLOGY OF THE RESEARCH}

\subsection{Objectives and Scope of the Research}

The main objective of the research is to establish what translation tools translators are using in various translation tasks quantitatively, and to relate them to the translation business in a way so as to propose an integrated model of translation from the perspective of localization project-based translation. In consolidating the model, we will also look at translator competences with the type of translation not specified as applied to various professional areas by default. Hence the research findings will be generalized within the scope of the integrated model.

The general hypothesis states that with the development of translation tools and software we tend to think in terms of translation universals which can better represent linguistic features of a particular language and simplify the translation process. These corpora are considered as huge databases, various forms of translation memory software and other advanced translation tools in order to facilitate and organize the translation process.

\subsection{Sampling, the Data Collection Tool and Data Analysis}

The survey on the translation tool use was aimed primarily at professional translators and was conducted among 73 respondents. The survey was distributed online to members of Facebook translation groups. Data collection was carried out in the form of a questionnaire drawn up with the help of the Google Form tool. The respondents were asked to choose the tools they use at different stages of their translation work.

\section{FINDINGS}

In one of the questions we focused on translation memory (TM) as one of most common tools nowadays. It is a database that stores predetermined units of a source language together with its translated equivalent. Repetitions and consistency are the two most prominent advantages of a TM. Repeated text is automatically translated from the database which saves time and effort. 
The survey shows that $54.9 \%$ of the translators interviewed are currently using TM tools. However, close to $13 \%$ stated that they are not familiar with TM systems. Among translators who do not use TM tools, only $2.8 \%$ pointed to cost being a factor which prevents them from using the tool. In second place, close to $9 \%$ stated that TM tools would not be useful for the kind of work they do. Other reasons were the difficulty involved in learning to use a TM tool and lack of time to search for a suitable one and learn how to use it (Fig. 1).

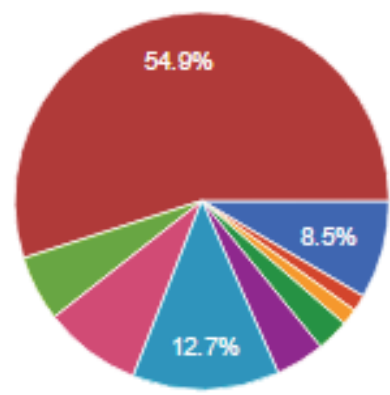

No time to search for a suitable one

and learn how to use it

Tried but unable to learn how to use...

Used one but no real benefit

Too expensive

Not suitable for the type of work

Not familiar with TM systems/tools

Yes, but not using them

Yes and having plans to use them

Currently using them

Figure 1. The use of TM software in translation work. A snapshot from the Google Forms data summary

Another question was intended to identify the range of translation tools used by translators (Fig. 2).

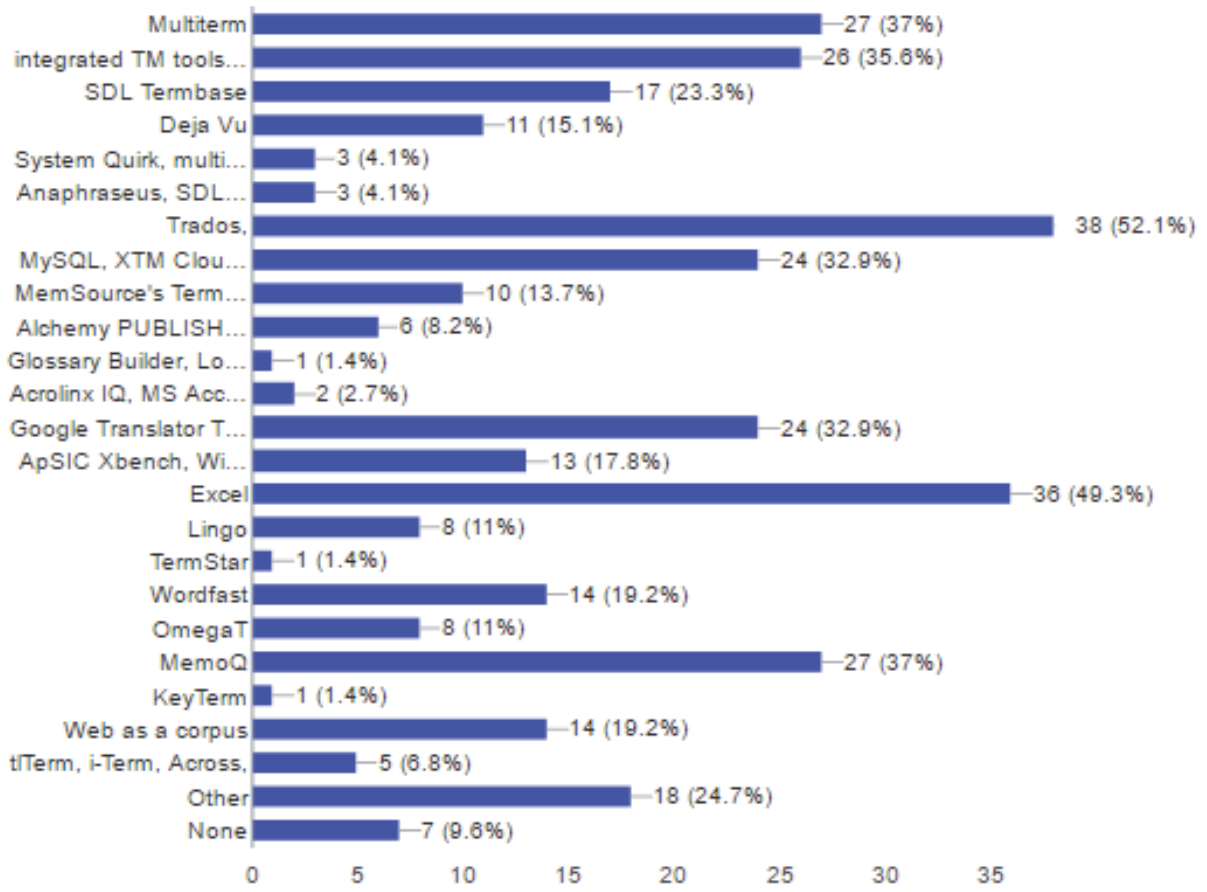

Figure 2. Using terminology management tools in the translation process. A snapshot from the Google Forms data summary 
The findings indicate that the choice is rather diverse. About 90 percent of translators rely heavily on the various translation technologies in their translation tasks. Working on Excel documents is seen as most common among translators. Excel document translations usually include various embedded elements, such as graphs, numbers, formulae and drop-down tabs, which need an expert team to be able to translate the subtle technicalities of the document. In addition, Excel spreadsheets are often employed in translation projects, so working in a team is possible.

Trados occupies the leading position as an integrated tool as it can create a simple and easy to use translation environment. The SDL Trados Studio project incorporates project management and computer-aided translation (CAT) tools for use by project managers, translators, editors, proofreaders and other language professionals [SDL Trados 2015]. This is followed by Multiterm and MemoQ as the terminology management application of TRADOS and integrated TM tools in CAT systems. XTM Cloud in line with Multitran, that accounts for $24 \%$ of respondents, provides a range of tools for the translator via the web. It is positioned as a fully featured TMS that provides a complete Translation Workflow solution and includes a CAT tool module on a unified platform. However, Logiterm and SDL WorldServer are least known and used by respondents presumably due to high costs (Logiterm) compared to alternatives and a very specific use (as SDL World Service is used for localization services).

In order to verify the survey findings concerning the technical competence of translators we investigated the content of the online forum on ProZ.com, one of the bestknown websites for translators that features discussions on various topics related to the translation industry. By searching the forum we intended to track the amount of technology related issues raised by translators among all the recent topics on the list. The selection process was based on the 100 most recent topics raised by translators from various professional backgrounds and provided by the topic distribution on the open discussion list of the ProZ.com website. The research showed that 31 out of the 100 topics were related to using translation technologies, such as SDL Trados, CAT Tools, Wordfast, MemoQ and XTM Cloud.

These findings correlate with the data collected from the survey above. According to the selected data from the forum, the SDL Trados system (58\%) is in the forefront in terms of its use by translators. The other technical tools are mentioned accordingly (CAT Tools - 16\%, Wordfast - 16\%, MemoQ - 6\%, and then XTM Cloud - 4\%) (Fig. 3).

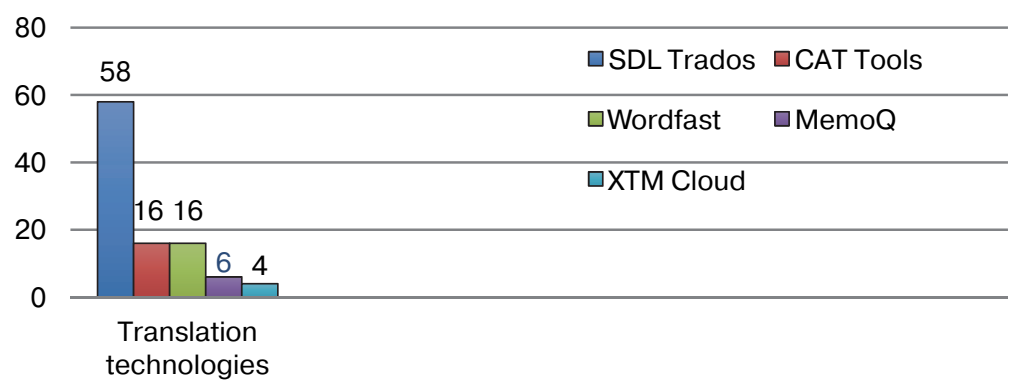

Figure 3. Translation technologies discussed in the online forum of ProZ.com 
The questions examined by translators online concern predominantly procedural knowledge related to the use of translation technologies in their job and problems related to misuse or lack of technical support that could affect the efficiency of the translation process. The top ten topics selected from the 100 most recent forum queries include:

1. Problems with TM tools

2. Operating term base

3. Creating a new TM for Studio from ttx files

4. Problems with upgrading Studio 2015

5. TM update

6. Compiling a report on a review of Trados 2015

7. Saving the MultiTerm form package

8. Problems with the Alignment Editor Service

9. Operating the LiveDocs Corpus in MemoQ

10. Problems with Auto-propagation in Wordfast Pro 5

Localization constitutes one of the four leading general technical issues of translation organized as a separate discussion column aligned with Smart shoppers, Rightto-left language (RTL) and Desktop Publishing (DTP).

The problems reviewed by translators provide a deeper insight into the complexities of using translation technologies which are designed to provide reliable support and to enhance the efficiency of translation activities. The increasing popularity of such online fora indicate an increasing demand for and interest in translation tools, as well as the level of competence required for contemporary translation tasks.

\section{DISCUSSION}

The localization industry is changing the role of translators by increasing the amount of competences they need to possess and this also makes the translation process itself a new and integrated reality. When translation competence comes into play in specialized translation tasks, there arises the question of complexity and heterogeneity, discussed by A. Neubert in his book Competence in Language, in Languages, and in Translation (2000) and later empirically validated with several experiments of the PACTE group (2003).

The complexity of the translation competence model suggested by the PACTE group lies in: "a system of sub-competences that are inter-related, hierarchical and that these relationships are subject to variations. These sub-competences include: a language sub-competence in two languages; an extra-linguistic sub-competence; an instrumental/professional sub-competence; a psychophysiological sub-competence; a transfer subcompetence; and a strategic sub-competence" (PACTE, 2003, p. 7).

The results of the theoretical findings and the survey indicate that the scope of the instrumental/professional sub-competence should be largely extended to include knowledge and abilities to deal with the practice of professional translation, all kinds of documentation, translation tools, automated translation programs and other technologies, as well as knowledge of the labor market.

The translation industry is developing complex integrated solutions to organize the translation process. Fragmentation concerns standardization efforts in support of content management and tool interoperability and localization processes (Fig. 4). 


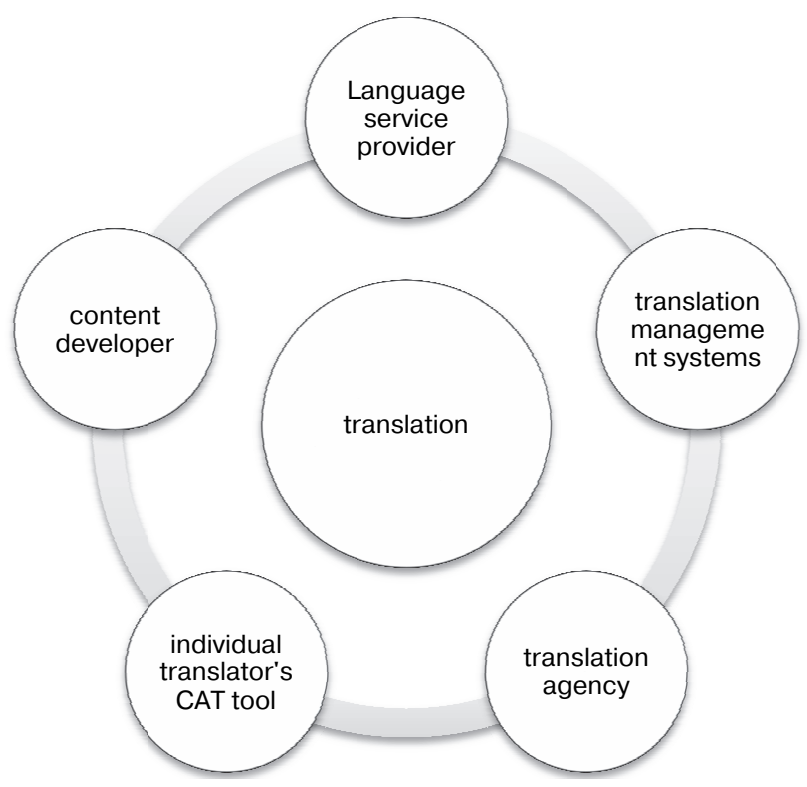

Figure 4. Integrated elements of the translation process within a localization project

The idea of integration permeates the translation process by unifying three core elements: content, service and personalization. Before being translated, the text is handed off from a content developer to a language service provider that recruits and manages in-house translators and freelancers. Then it is transferred to a translation management system as an open standard-based architecture where linguistic data and the application of reusable content are shared via workflow automation based on business rules and project information held in its knowledge base. At this stage, information is tracked through every step in the translation process whether using internal or external resources. After that, via a translation agency, the translation goes to a CAT tool for further processing. In addition, the role of adaptation and cooperation is increasing. When working on a localization project, for example, translation is aligned with adaptation of various components, such as demos, sample files and tutorials.

Observations based on the level of technical expertise and survey data of the variety of online resources used by a modern translator encourage us to consider the growing convergences between a translator and a technical writer, which leads to a change in the way we can map the translation process. All translation tools create a certain integrated translation environment with the translator acting as a moderator and a good manager to organize the work the way he/she sees it best.

The research findings brought us to the conclusion that apart from the core translator's competences, there should be translation tool competence and management skills that form an integral part of the translation task. Technological, managerial and research skills are embedded into the integrated pattern of translating within the localization industry, since this implies having internal stages and subtasks, which are inseparable from the core activities, most of which are done by the translator (Fig. 5). 


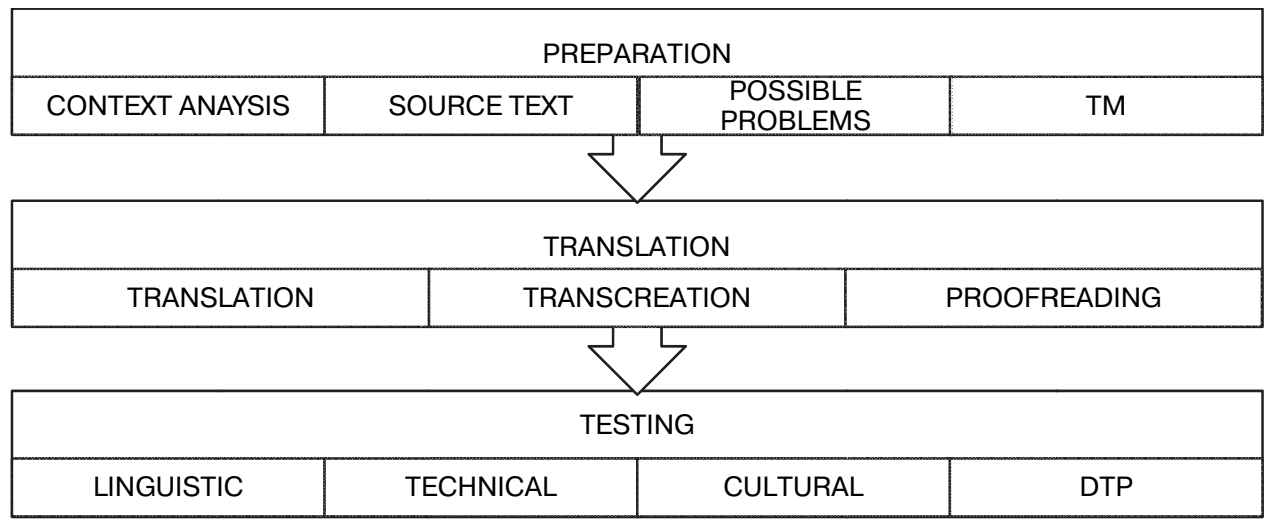

Figure 5. Translation activities within the localization industry

A technical translator's job is based on a project. The preparation stage includes working on specifications, drawing up terminology and phraseology using TM and other tools. The translation itself may be seen as the least interesting part, since it is done on carefully selected predetermined items. This is followed by checking, reviewing or proofreading, certifying and delivering. During the testing period the translator can still be consulted. This then completes the translation activities under the project.

Localization requires translators to possess strong instrumental and technical skills in addition to traditional translation and domain expertise with a wide range of new and progressive tools that a technical translator knows how to use. Desktop or browserbased (DTP) tools, computer assisted translation (CAT) tools, integrated terminology management tools, integrated content management systems (CMS) and automatic file transfer protocols (FTP) are just a few of the many facilities that are intended to make internationalization more efficient. Besides, internationalization implies that the text is sent to a translator in very small-sized files (strings and information chunks) which can be easily edited and then localized. However, this process is cognitively more complex, since a translator must try to comprehend the text without the context by constructing a situation model, or a prototype.

Thus, it is important to note that translation tasks carried out under a localization project are different from traditional translation tasks: 1) technical elements are embedded and supervised; 2) compliance with specific standards of the project is required, depending on the localization strategy; 3 ) translators should manufacture the product and describe it at the same time; 4) expertise in working with specialized software and different formats is needed.

\section{CONCLUSIONS}

Translation technologies make technical discourse non-linear in terms of production and reception. Localization changes traditional understanding of the translation process due to the relation between translation and internationalization. Before going from a piece of software developed for the international market to a finished translation, the product is first prepared by stripping all the specific features and making it generate a base translation in order to localize. 
Over its three decades the concept of localization has expanded to include nondigital and non-verbal issues of product adaptation often addressed through supporting' terminology, such as transcreation, rewriting, versioning or transrepresentation. As assumed by Achkasov, "The conceptual potential of the term "localization" seems to exceed all other variants of naming linguistic, cultural, social, economic, political, legal, etc., aspects of product adaptation and is increasingly favored in industry, related research, academia and even Translation Studies as a generic concept for all types of complex content modifications (Achkasov 2017: 289).

Therefore, localization goes beyond translation and adapts the source content to the culture of the place where the translated text is to be used. In addition to translation, other tasks include project management, software engineering, testing, and desktop publishing. At the translation stage, translators work on terminology databases, maintaining TMs, and using and maintaining MT applications.

To sum up, GILT can be viewed as an integrated chain with every step having an impact on the next. Translation norms and equivalence are incorporated into the system through the use of specialized software which makes it work in certain modes, such as foreignizing, domesticating, internationalizing and localization.

Among the newest trends predicted for 2017, in the area of globalization and the localization industry that are listed on the GALA (Globalization and Localization Association) website, we can observe the continuing development of Neural MT and Deep Learning, which claims to be a positive innovation of the future. (URL). Neural MT is based on neural network technology, which is a high-powered approach to Artificial Intelligence (AI) and machine learning. As opposed to traditional statistical MT methods, neural MT examines an entire sentence before suggesting the best possible translations. This new model provides translations that are more fluent and readable than ever before. Tilde Neural MT achieves this success by taking into account elements such as word reordering, dependencies, morpho-syntactic agreements, and other features that are not handled well by statistical MT. The main advantages of neural MT include 1) more fluent, human-like translations; 2) higher translation quality and accuracy; 3) context is taken into account and 4) it is better for under-resourced languages with less data (URL).

Yet, the question of the role of the translator and the inherent complexities of the translation process still remains open, since at a time dominated by technology and media, the contribution of human translators is still difficult to overestimate. We concur with the following assumption of Snell-Hornby (2006: 172): "Responsibility for the final product of translation can only be assumed by the translator if $\mathrm{s} / \mathrm{he}$ is granted it in the first place and is not treated as a 'powerless' transcoder providing raw material for further processing by the 'real' specialist or artist".

(C) Irina N. Remkhe, Liliya A. Nefedova, David C. Gillespie, 2017

\section{REFERENCES}

Catford, J. C. (1965) A Linguistic Theory of Translation. An Essay in Applied Linguistics. London: Oxford University Press.

Cuellar, S. B. (2008) Towards an Integrated Translation Approach. Proposal of a Dynamic Translation Model (DTM). Dissertation zur Erlangung des Grades des Doktors der Philosophie bei der Fa- 
kultät für Geisteswissenschaften Departements Sprach-, Literatur- und Medienwissenschaften I und II der Universität Hamburg.

Dunne, K J. (2015) Localization: In: Routledge encyclopedia of translation technology / edited by SinWai Chan. Routledge. P. 550-556.

Esselink, B. (2000) A Practical Guide to Localisation, Amsterdam: Benjamins.

Fedorov, A. V. (1953) Osnovy Obshchey Teorii Perevoda [Introduction into Translation]. Izdatel'stvo literatury na inostrannykh yazykakkh.

Globalization and localization association. Available from: www.gala-global.org.

Jakobson, R. (1959/2000). On Linguistic Aspects of Translation. In L. Venuti L (ed.). The Translation Studies Reader, New York. 2000 P. 113-118.

Komissarov, V. N. (1973). Slovo o perevode [Towards the Issue of Translation]. M.: Mezhdunarodnye otnosheniya.

Munday, J. (2008) Introducing Translation Studies: Theories and Applications. 2nd ed. London/ New York: Routledge, 2008.

Neubert, A. (2000) Competence in Language, in Languages, and in Translation. In Developing Translation Competence, C. Schäffner and B. Adabs (eds.), 3-18. Amsterdam: John Benjamins.

Newmark, P. (1981) Approaches to Translation, Oxford and New York: Pergamon.

Nida, E. (1964) Toward a Science of Translating. Leiden: E. J. Brill.

Olohan, M. (2016) Scientific and Technical Translation, London and New York: Routledge.

PACTE (2003) Building a Translation Competence Model. In: ALVES, F. (ed.). Triangulating Translation: Perspectives in Process Oriented Research, Amsterdam: John Benjamins. Available from: http://www3.uji.es/ aferna/EA0921/3b-Translation-competence-model.pdf.

Panou, D. (2013) Equivalence in Translation Theories: A Critical Evaluation. In: Theory and Practice in Language Studies. Vol. 3, No. 1, P. 1-6.

Pym, A. (2004) The Moving Text: Localization, translation, and distribution / Benjamins Translation Library. Volume 49.

Reiss, K. \& Vermeer, H. J. (1984/1991) Grundlegung einer allgemeinen Translationstheorie. 2nd edition. Tübingen: Max Niemeyer Verlag.

Remkhe I., Nefedova L., GillespieD. From function to system: advances in choosing a matrix structure of the translation process // Russian Journal of Linguistics. Vestnik RUDN, 2016, 20 (3), pp. 229-241.

Retsker, Y. I. (1974) Teoriya Perevoda i Perevodcheskaya Praktika [The Theory of Translation and Translation Practice]. M.: Mezhdunarodniye otnosheniya.

Shveitser, A. D. (1988) Teoriya Perevoda. Status, Problemy, Aspekty [Translation Theory. Status, Problems, Aspects]. Moscow: Nauka.

Snell-Hornby, M. (1988) Translation Studies: An Integrated Approach — revised edition, Amsterdam/Philadelphia, John Benjamins Publishing Company, 1995. First Edition.

Snell-Hornby, M. (2006) The Turns of Translation Studies: New Paradigms or Shifting Viewpoints? Benjamins Translation Library Vol. 66. Amsterdam/Philadelphia: John Benjamins, 2006.

TILDE Neural MT. Available at: http://www.tilde.com/mt/neuralMT.

\section{Article history:}

Received: 10 August 2017

Revised: 05 September 2017

Accepted: 25 September 2017 


\title{
For citation:
}

Remkhe, I., Nefedova, L., Gillespie, D. (2017) Rethinking the Translator's Role within the GILT project: an integrated approach. Russian Journal of Linguistics, 21 (4), 910-926. DOI: 10.22363/2312-9182-2017-21-4-910-926.

\section{Bio Notes:}

Dr. Irina N. Remkhe, Associate Professor in the Department of Theory and Practice of Translation, Faculty of Linguistics and Translation, Chelyabinsk State University. Research interests: cognitive linguistics, intercultural communication, psycholinguistics, theory and practice of translation. Contact information:e-mail: rilix@mail.ru

Liliya A. Nefedova, Professor in the Department of Romance and Germanic Languages and Intercultural Communication, Faculty of Linguistics and Translation, Chelyabinsk State University. Research interests: general linguistics, theory of communication, intercultural communication, cognitive linguistics, theory and practice of translation. Contact information:e-mail: lan2@mail.ru

David C. Gillespie, Professor in the Department of Politics, Languages and International Studies, University of Bath. Research interests: Russian literature and film, Russian culture in the post-Soviet era. Contact information: e-mail: dcgillespie41@gmail.com

\section{FINANCE AND ACKNOWLEDGEMENTS}

This research is funded by the Russian State request for project completion \#34.6111.2017/BC "Translating Media Texts within the Context of Modern Tendencies in Mass Communication".

\section{РОЛЬ ПЕРЕВОДЧИКА В УСЛОВИЯХ РЕАЛИЗАЦИИ ПРОЕКTA GILT (ГЛОБАЛИЗАЦИЯ, ИНТЕРНАЛИЗАЦИЯ, ЛОКАЛИЗАЦИЯ, ПЕРЕВОД): ИНТЕГРИРОВАННЫЙ ПОДХОД}

\author{
И.Н. Ремхе ${ }^{1}$, Л.А. Нефедова ${ }^{1}$, Д.Ч. Гиллеспи ${ }^{2}$ \\ ${ }^{1}$ Челябинский государственный университет \\ 454001 Челябинск, Россия, ул. Бр. Кашириных, 129 \\ ${ }^{2}$ Университет г. Бат \\ Claverton Down, Bath, North East Somerset BA2 7AY, United Kingdom
}

\begin{abstract}
В статье освещается проблема модификации роли переводчика в условиях глобализации, которая претерпевает значительные изменения за последние десятилетия. От выполнения функции медиатора между текстами на языке оригинала и перевода современный переводчик переходит к созданию собственного интегративного пространства на основе цифровой обработки текстов и использования виртуальных баз данных. В рамках интегративного подхода авторы рассматривают эквивалентность перевода с позиции нейтрализации, заключающейся в необходимости соответствовать установленным переводческим нормам наряду с передачей коммуникативной цели высказывания и учета контекста, включая особенности языкового и надъязыкового характера. При этом в условиях развития локализации переводческие нормы занимают особое положение в инкорпорированной части переводческих программ, использование которых осуществляется с учетом процессов форенизации, доместикации и интернационализации. Таким образом, современная парадигма глобализации перевода в рамках проекта GILT открывает новые возможности для развития концептуально нового направления в переводе, определяющего поиск интегративных решений в переводческом процессе.
\end{abstract}

Ключевые слова: интегрированный подход, модель перевода, эквивалентность, локализация, интернационализачия, глобализаџия 


\section{История статьи:}

Дата поступления в редакцию: 10 августа 2017

Дата принятия к печати: 25 сентября 2017

\section{Для цитирования:}

Remkhe, I., Nefedova, L., Gillespie, D. (2017) Rethinking the Translator's Role within the GILT project: an integrated approach. Russian Journal of Linguistics, 21 (4), 910—926. DOI: 10.22363/2312-9182-2017-21-4-910-926.

\section{Сведения об авторах:}

Ремхе Ирина Николаевна, кандидат филол. наук, доцент кафедры английского языка, Институт Истории, филологии и иностранных языков, Магнитогорский государственный технический университет им. Г.И. Носова. Сфера научных интересов: когнитивная лингвистика, межкультурная коммуникация, психолингвистика, теория и практика перевода. Контактная информация: e-mail: rilix@mail.ru

Нефедова Лилия Амиряновна, доктор филол. наук, профессор, профессор кафедры романо-германских языков и межкультурной коммуникации, факультет лингвистики и перевода, Челябинский государственный университет. Сфера научных интересов: общее языкознание, теория коммуникации, межкультурная коммуникация, когнитивная лингвистика, теория и практика перевода. Контактная информачия: e-mail: lan2@mail.ru

Давид Чарльз Гиллеспи, доктор наук, профессор русского языка, факультет политики, языков и межкультурных отношений, Университет г. Бат (Великобритания). Сфера научных интересов: русская литература, русский кинематограф, русская культура в постсоветский период. Контактная информащия: e-mail: d.c.gillespie@bath.ac.uk 